\title{
Bibliometric analysis of publications on Campylobacter: (2000-2015)
}

\author{
Waleed M. Sweileh ${ }^{1 *}$, Samah W. Al-Jabi ${ }^{2}$ Ansam F. Sawalha', Adham S. AbuTaha ${ }^{1}$ and Sa'ed H. Zyoud ${ }^{2}$
}

\begin{abstract}
Background: Campylobacter species are widespread zoonotic pathogens. Campylobacter jejuni causes a form of gastroenteritis called campylobacteriosis. Campylobacter drug resistance is considered a serious threat. In order to better understand national and international research output on Campylobacter, we conducted this bibliometric overview of publications on Campylobacter. This study can be used to assess extent of interaction and response of researchers, food regulators, and health policy makers to global burden of campylobacateriosis.

Methods: Scopus database was used to retrieve publications with the following keywords (Campylobacter) campylobacteriosis, C. jejuni, C. coli). The study period was set from 2000 to 2015. All types of journal documents, excluding errata, were considered. Bibliometric indicators such as annual growth of publications, country contribution, international collaboration, and citation analysis were presented. The quality of retrieved data was indirectly assessed by Hirsch index and impact factor of journals.
\end{abstract}

Results: A total of 5522 documents were retrieved with median (Q1-Q3) citations of 9 (2-23) and $h$-index of 113. Annual number of publications showed a fluctuating increase. The core leading journals were Applied and Environmental Microbiology journal and Journal of Food Protection with 246 (4.46\%) publications for each. The USA (1309; 23.6\%) was the most productive country while Danmarks Tekniske Universitet (150; 2.7\%) was the most productive institution. Half of the top ten productive countries were European. France had the lowest percentage (33.5\%) of articles with international collaboration while Netherlands (57.7\%) had the highest percentage of articles with international collaboration. Approximately half (50.1\%) of retrieved articles were published in journals under the subject area of "immunology/microbiology". Main themes in highly cited articles were molecular biology/genetics and public health burden of campylobacteriosis. There were 728 (13.1\%) articles on campylobacter-related drug resistance, and the top cited articles focused mainly on increasing resistance to quinolones and fluoroquinolones.

Conclusions: There was a clear increase in number of publications on Campylobacter. Rational use of antimicrobials in humans, poultry, and animals is highly recommended. International collaboration is highly required particularly in implementing new diagnostic screening technologies to minimize global health burden of Campylobacter and ensure food safety.

Keywords: Campylobacter, Bibliometrics

\footnotetext{
* Correspondence: waleedsweileh@yahoo.com

'Department of Physiology, Pharmacology and Toxicology, College of Medicine and Health Sciences, An-Najah National University, Nablus, Palestine

Full list of author information is available at the end of the article
}

(c) The Author(s). 2016 Open Access This article is distributed under the terms of the Creative Commons Attribution 4.0 International License (http://creativecommons.org/licenses/by/4.0/), which permits unrestricted use, distribution, and reproduction in any medium, provided you give appropriate credit to the original author(s) and the source, provide a link to the Creative Commons license, and indicate if changes were made. The Creative Commons Public Domain Dedication waiver (http://creativecommons.org/publicdomain/zero/1.0/) applies to the data made available in this article, unless otherwise stated. 


\section{Background}

Campylobacter species are zoonotic pathogens [1]. Many animals and birds, particularly broiler chickens, carry Campylobacter asymptomatically and shed the microorganism in their feces [2]. Campylobacter jejuni is the most important species of Campylobacter. The pathogen is transmitted to people mainly through eating undercooked poultry meat or from contaminated food or animal products [3]. C. jejuni has been implicated in a form of gastroenteritis called campylobacteriosis [4]. People with campylobacteriosis will have diarrhea, cramping, and fever within few days of exposure to Campylobacter [5-7]. Asymptomatic Campylobacter infections are usually common and endemic in developing regions like Middle East, Africa, and South Asia, with children being most affected [8-10]. However, asymptomatic Campylobacter infections are uncommon in developed regions [11].

The exact incidence of campylobacteriosis at the global and national levels is poorly known. However, the past decade has witnessed an increase in global incidence of campylobacteriosis [7, 12]. A survey study on foodborne illnesses in the USA indicated that $9 \%$ of these illnesses were caused by Campylobacter compared to $58 \%$ for norovirus [13]. In the USA, Campylobacter is the most common bacterial cause of diarrheal illness [14]. It is also estimated that Campylobacter affects over one million people every year causing death in 76 patients every year in the USA [15]. In the UK, it has been reported that campylobacter affects an estimated half a million people annually and kills approximately 100 [16]. In the UK, the reported incidence of campylobacteriosis was estimated to be 9.3 per 1000 person-years while that in Netherlands was 5.8 per 1000 person-years [17-19].

In response to worldwide concern of foodborne gastroenteritis caused by $C$. jejuni, World Health Organization (WHO) is developing policies that will further promote the safety of entire food chain [20]. Campylobacteriosis is usually a self-limiting disease. However, in certain cases, antibiotics such as macrolides or flouroquinolones might be needed. Unfortunately, worldwide reports of drugresistant Campylobacter in humans, poultry, and food have been published which threatens our goal of treating millions of people around the world [21-26]. The CDC considers Campylobacter drug resistance as a serious threat [27].

There are several published bibliometric studies on specific pathogenic bacteria or gastrointestinal diseases, or zoonosis in general [28-33]. However, none was carried out about Campylobacter and its related drug resistance profile. Therefore, we carried out this bibliometric analysis to assess worldwide research productivity on Campylobacter. In specific, the following bibliometric indicators will be presented in this study: annual growth of publications, citation analysis, country and institutional contribution, highly cited articles, international collaboration, and journals most active in publishing research on Campylobacter.

This study is in line with the WHO recommendations in its latest report on campylobacteriosis in which the panel of consultation experts recommended several actions to be taken to better understand and control Campylobacter [34]. Furthermore, diarrheal diseases are considered to have major global burden, and research in this area is needed [35]. This study will be important for researchers, clinicians, and health policy makers in order to adopt stringent policies regarding veterinary practices, food processing, antibiotic use, and preventive measures to control campylobacteriosis. Furthermore, this bibliometric analysis can assess areas of national and international research strengths, highlight knowledge and evidence gaps, provide a dataset of institutional and individual expertise which explore different disciplines covering campylobacter-related health research.

\section{Methods}

For the purpose of this study, the authors chose Scopus database (https://www.scopus.com) to retrieve all possible documents related to Campylobacter. Of course, the choice of Scopus was based on the understanding of the authors that it is the largest and most comprehensive database [36]. Furthermore, Scopus has been previously used in many published bibliometric studies [37-42].

The search strategy used in this study consisted of several steps. The first step was finding the correct and comprehensive keywords. For the purpose of this study, we use the following keywords: Campylobacter* or "C. jejuni" or "C. coli". The asterisk was used in search query to retrieve documents with keywords such as Campylobacter or campylobacteriosis. The keywords "C. jejuni" and "C. coli" were used in search query because some publications might include the abbreviation name instead of full name, and therefore, these terms were used in search query. Quotation marks were used to increase accuracy of search query. Keywords were used in title search rather than title/abstract search. The title search will yield minimum false positive documents, and therefore, it is an accurate approach. However, the title/ abstract search will yield many false positive results in which the main focus is not on Campylobacter per se [43-51]. It is true that "title search" might lead to loss of some documents (false negative), but the error (false positive) obtained by "abstract search" will be greater. In this study, the authors tried the title/abstract search and title search scenarios and found that there were 3306 document differences between the two scenarios. Manual review by authors of top 100 cited articles of these 
3306 documents showed that Campylobacter keyword was mentioned in these articles as a marginal keyword rather than an essential part of the article itself. Based on this, the authors decided to go with the title search rather than the title/ abstract search.

The second step in the search strategy was to limit the search query to the required specifications. In this study, the search query was limited to study period between years 2000 and 2015. This is easily done because Scopus allows researchers to specify the time period for the search query. Scopus also lists the type of retrieved documents, e.g., journal articles or books. In this study, only journal articles were included in the study while nonjournal articles such as books and book chapters were excluded. Finally, some journal articles were actually just corrections of mistakes in previously published articles. Such corrections (errata documents) were excluded because they do not represent a publication. Figure 1 shows a scheme of the steps followed to retrieve data pertaining to this study. In each step, the total number of documents retrieved was mentioned.

Scopus has a function called languages. In this function, the frequency of articles written in English or any other languages is listed. No articles were excluded based on language. Based on Scopus policy, all published articles indexed in Scopus must have an English abstract. Therefore, even articles with non-English language such as Chinese do have an English title and abstract that facilitates content analysis.

The third step after obtaining the required documents was to analyze the data to provide bibliometric indicators. One of these bibliometric indicators is national research productivity and extent of international collaboration. Scopus provides automatic country analysis for any retrieved data. Scopus has a side bar with functions that can help researchers analyze data and obtain the required indictors. One of these functions is country affiliation. In Scopus, publications can be

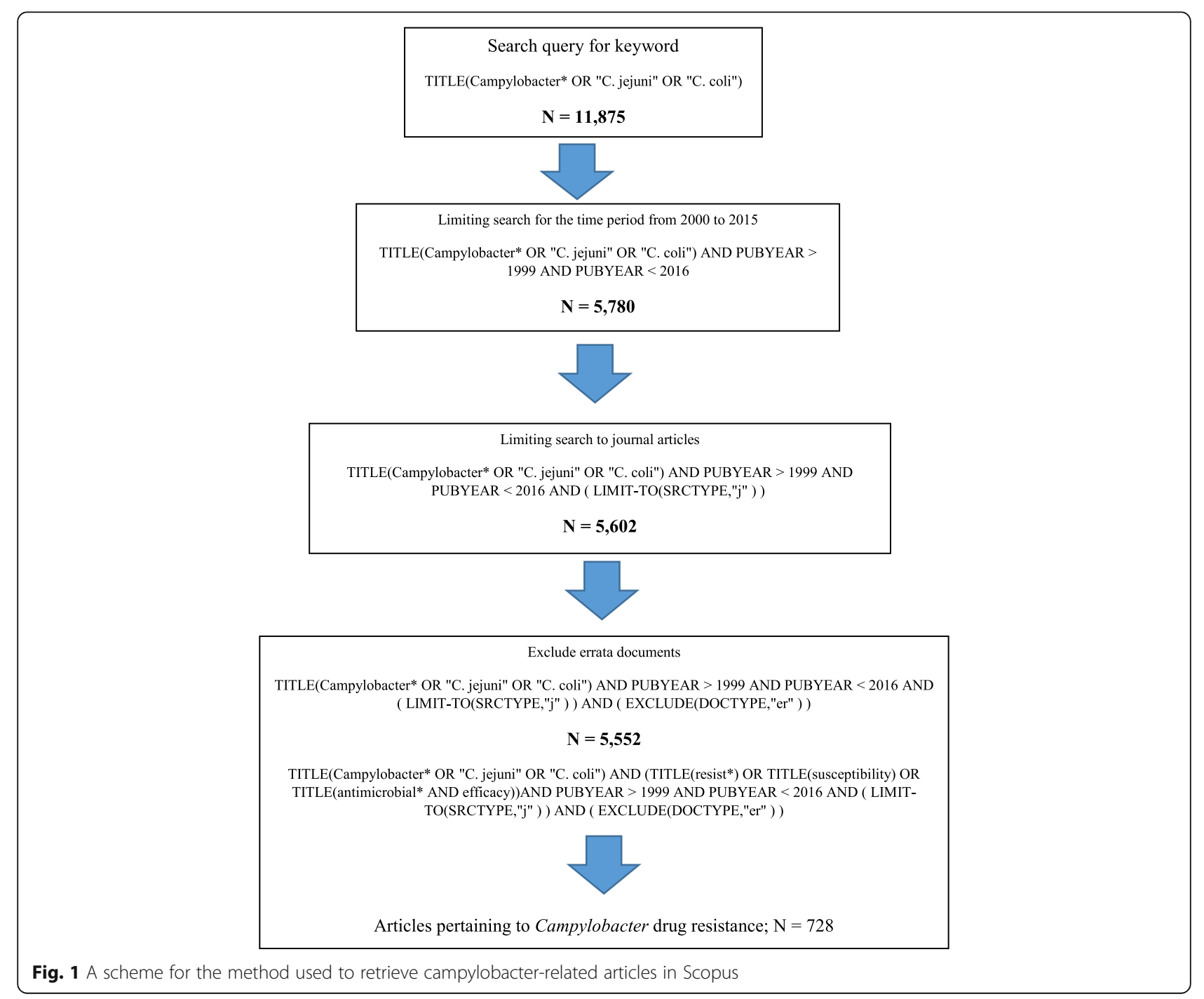


divided into two types: (1) single country publications (SCP) which represent inter-country publication because the authors of the publication belong to different countries. Other bibliometric indicators to be obtained from retrieved data include the most active institutions, journals, and authors. Furthermore, retrieved data can be categorized based on subject areas. This function is available in Scopus side bar in which documents are categorized based on the scope of the journal publishing that document. For example, subject area "medicine" which includes all articles published in journals within the scope of medicine. The same applies to subject area "Biochemistry" and other subject areas. All these bibliometric indicators can be obtained from Scopus directly by using the bar side functions of Scopus which include functions such as intuition, author, and journals.

Strength and impact of publications which represents quality is difficult to measure in a direct way. However, several indicators could be used to evaluate the strength and quality of publications in an indirect way. Such indirect quality indicators include the total number of citations received, average number of citations per article, Hirsch index ( $h$-index), percentage of highly cited articles, and impact factor (IF) of journals publishing the documents of interest. $h$-index was originally developed to assess and rank researchers [52]. However, $h$-index can be used to rank countries and academic institutions [52]. In this study, $h$-index was obtained directly from Scopus database while IF was obtained from the Journal Citation Reports 2015 published by Thompson Reuters [53].

The standard competition ranking (SCR) was used for ranking purposes of most productive (active) countries, institutions, journals, and authors. Graphs were created using the Statistical Package for Social Sciences software (SPSS for windows, 21) while tables were created using Microsoft Excel. Ethical approval of this study was not required by the Institutional Review Board since no human subjects or data were involved. All data analyses were carried out on October 25th, 2016. The number of publications retrieved in this study can be retrieved by other researchers with high reproducibility using the search query shown in Fig. 1. Furthermore, the excel sheet of retrieved articles is attached for those who are interested (annex 1).

\section{Results}

General information

The search query yielded 5552 journal articles (Fig. 1). A total of 5160 (92.9\%) articles were written in English while the remaining articles were written in non-English, such as Spanish (72, 1.3\%), German (58, 1.0\%), Polish (52, 0.9\%), Chinese (51, 0.9\%), and French (41, 0.7\%). A total of $4889(88.0 \%)$ articles were research articles while the remaining were review articles (294, 5.3\%), letters (164, 3.0\%), conference papers $(71,1.3 \%)$, notes (58, $1.0 \%)$, short survey articles $(35,0.6 \%)$, articles in press (27, $0.5 \%)$, and editorials $(14,0.3 \%)$.

\section{Growth of publications and citation analysis}

The annual number of publications showed a fluctuating rise with time and reached a maximum of 448 articles in 2014. There was a twofold increase in the number of publications during the study period. The total number of citations for retrieved articles was 110,160 , an average \pm standard deviation of $19.8 \pm 38.5$ citations per article. The median (interquartile range) of the number of citations received was nine (2-23). The $h$-index of retrieved articles was 113 , meaning that at 113 documents of retrieved articles were cited at least 113 times, and this number might increase with time. Table 1 shows the annual number of publications from year 2000 to 2015 along with citation analysis for each year. As expected, the average number of citations per article was highest (48.6) for old articles, those published in year 2000, and was lowest (1.5) for new articles, those published in year 2015.

\section{Subject areas}

Retrieved documents were published in journals that belong to different subject areas. The majority (2783,

Table 1 Annual number of publications and citations on Campylobacter (2000-2015)

\begin{tabular}{llclr}
\hline Year & Number of publications & $\% N=5552$ & $T C$ & $C / A$ \\
\hline 2015 & 383 & 6.9 & 587 & 1.5 \\
2014 & 448 & 8.1 & 1575 & 3.5 \\
2013 & 435 & 7.8 & 29,19 & 6.7 \\
2012 & 386 & 7.0 & 3700 & 9.6 \\
2011 & 408 & 7.3 & 4978 & 12.2 \\
2010 & 403 & 7.3 & 5639 & 14.0 \\
2009 & 392 & 7.1 & 6476 & 16.5 \\
2008 & 359 & 6.5 & 6826 & 19.0 \\
2007 & 384 & 6.9 & 9346 & 24.3 \\
2006 & 351 & 6.3 & 8276 & 23.6 \\
2005 & 338 & 6.1 & 9912 & 29.3 \\
2004 & 287 & 5.2 & 9582 & 33.4 \\
2003 & 295 & 5.3 & 10,525 & 35.7 \\
2002 & 239 & 4.3 & 9780 & 40.9 \\
2001 & 256 & 4.6 & 10,630 & 41.5 \\
2000 & 188 & 3.4 & 9138 & 48.6 \\
\hline
\end{tabular}

TC total citations, C/A number of citations per article calculated by dividing the total number of citations retrieved for each year by the total number of publications for that year 
50.1\%) was published in journals under the subject area of "immunology and microbiology". Other common subject areas encountered were "medicine" (2471, 44.5\%), "agricultural and biological science" (1625, 29.3\%), and "biochemistry, genetics, and molecular biology" (1496, $26.9 \%)$. It should be noted here that there is an overlap in subject areas. For example, a certain specific journal could fit in more than two categories such as medicine and immunology/microbiology. Therefore, the sum of the percentage of all subject areas exceeded $100 \%$. Table 2 shows the top ten subject areas of retrieved articles. The subject area "engineering" represents articles published mainly in the journal of International Journal of Food Microbiology. The subject area "chemistry" represents articles published in diverse journals that discuss chemical aspects of campylobacter microorganism.

\section{Most productive (active) countries}

Countries that were most productive (active) in publishing documents on campylobacter were listed in Table 3. The USA was the most productive country (1309, 23.6\%) followed by UK (829, 14.9\%) and Canada (472; 8.5\%). However, Netherlands ranked first (34.3) followed by UK (32.7) and Denmark (32.2) when countries were ranked based on the mean number of citations per article. Six countries in the top ten productive countries were in Europe. A total of 352 (6.3\%) articles were authored or co-authored by all African and Middle Eastern countries. France had the lowest percentage (33.5\%) of articles with international authors while Netherlands (57.7\%) had the highest percentage of articles with international authors (Table 3).

Table 2 Top ten subject areas of publications on campylobacter (2000-2015)

\begin{tabular}{lllc}
\hline $\mathrm{SCR}^{\mathrm{a}}$ & Subject area & Frequency & $\% \mathrm{~N}=5552$ \\
\hline 1st & Immunology and microbiology & 2783 & 50.1 \\
2nd & Medicine & 2471 & 44.5 \\
3rd & $\begin{array}{l}\text { Agricultural and biological } \\
\text { sciences }\end{array}$ & 1624 & 29.3 \\
4th $\quad \begin{array}{l}\text { Biochemistry, genetics and } \\
\quad \text { molecular biology }\end{array}$ & 1496 & 26.9 \\
5th $\quad$ Veterinary & 667 & 12.0 \\
6th $\quad$ Environmental science & 437 & 7.9 \\
7th $\quad \begin{array}{l}\text { Pharmacology, toxicology, } \\
\quad \text { and pharmaceutics }\end{array}$ & 185 & 3.3 \\
8th & Engineering & 130 & 2.3 \\
9th $\quad$ Chemistry & 102 & 1.8 \\
10th & Neuroscience & 83 & 1.5 \\
\hline
\end{tabular}

Equal countries were given the same ranking number, and then a gap is left in the ranking numbers

${ }^{a} S C R$ standard competition ranking
Most productive (active) institutions/organizations, authors, and journals

The most productive institution was the Technical University of Denmark (150; $2.7 \%)$ followed by the USDA ARS Russell Research Center RRC (USA) (2.5\%) and Wageningen University and Research Centre (Netherlands) (2.0\%). Three institutions in top ten productive institutions are located in the USA, two are in Netherlands, and two in the UK (Table 4). The Belfast Health and Social Care Trust is neither a university nor a research center yet ranked fourth with 108 publications. Analysis of these publications showed that 87 $(80.5 \%)$ were collaborative articles between scientists in Belfast Health and Social Care Trust with researchers in universities and other research centers.

The top ten productive authors are shown in Table 5. Four authors in the top ten productive list are from the UK, three from the USA, one is affiliated with WHO center, one from Japan, and one from Finland. The top ten productive journals in publishing articles on Campylobacter is shown in Table 6. The most active journal was the Applied and Environmental Microbiology followed by the Journal of Food Protection with 246 $(4.4 \%)$ articles for each (Table 6). All journals in the top ten list had an impact factor. The range of IF for journals in top active list was from 1.67 to 3.99. All journals in the top ten list, with the exception of Plos One, are in specific field of microbiology, infection, food, poultry, or immunology. Three journals (Plos One, Infection and Immunity, and Foodborne Pathogens and Disease) in the top ten list follow an open access policy.

\section{Top cited articles}

The top cited articles on Campylobacter [54-63] are shown in Table 7. The top cited articles were mostly in the field of molecular biology, pathophysiology, and public health. The highest number of citations attained was 1203 for an article on the molecular biology published in Nature. The top ten cited articles included seven research articles and three review articles.

\section{Resistance profile}

Analysis of retrieved documents for articles pertaining to Campylobacter drug resistance resulted in 728 articles, i.e., $13.16 \%$ of the total retrieved articles. The total number of citations received by articles on resistance was 14,191 , a mean \pm SD of $19.5 \pm 30.2$ citations per article and a median (IQR) of 10 (3-24). The $h$-index of retrieved articles on resistance was 53. Annual number of publications on drug-resistant Campylobacter showed a dramatic increase starting from year 2002 followed by a fluctuating plateau (Fig. 2). The dramatic increase in number of publications observed in 2002 was associated with 11 articles on the emergence of quinolone/ 
Table 3 Top ten productive (active) countries in publishing articles on Campylobacter (2000-2015)

\begin{tabular}{llllllllll}
\hline SCR & Country & Frequency & $\%$ N $=5552$ & TC & C/A & SCP & Percent & MCP & Percent \\
\hline 1st & USA & 1309 & 23.6 & 36,321 & 27.7 & 847 & 64.7 & 462 & 35.3 \\
2nd & UK & 829 & 14.9 & 27,082 & 32.7 & 468 & 56.5 & 361 & 43.5 \\
3rd & Canada & 472 & 8.5 & 12,526 & 26.5 & 252 & 53.4 & 220 & 46.6 \\
4th & Japan & 310 & 5.6 & 4508 & 14.5 & 178 & 57.4 & 132 & 42.6 \\
5th & Germany & 275 & 5.0 & 4606 & 16.7 & 165 & 60.0 & 110 & 40.0 \\
6th & Denmark & 258 & 4.6 & 8315 & 32.2 & 143 & 55.4 & 115 & 44.6 \\
7th & Netherlands & 239 & 4.3 & 8199 & 34.3 & 101 & 42.3 & 138 & 57.7 \\
8th & France & 218 & 3.9 & 4433 & 20.3 & 145 & 66.5 & 73 & 33.5 \\
9th & Australia & 197 & 3.5 & 3524 & 17.9 & 108 & 54.8 & 89 & 45.2 \\
10th & New Zealand & 164 & 3.0 & 3051 & 18.6 & 88 & 53.7 & 76 & 46.3 \\
\hline
\end{tabular}

$S C R$ standard competition ranking, TC total citations, $C / A$ number of citations per article calculated by dividing the total number of citations retrieved for each country by the total number of publications for that country, $h$-index Hirsch index, SCP single country publication (intra-country collaboration), MCP multiple country publications (inter-country publications)

fluoroquinolone resistance in Campylobacter. Top productive countries on Campylobacter drug resistance are shown in Table 8. Countries such as China (seventh) and Ireland (tenth) were among the top ten productive countries. The Iowa State University $(38,5.2 \%)$ was the most productive institution. The top ten cited articles [56, 64-72] are shown in Table 9. Four articles discussed on resistance to flouroquinolones. The article that received the highest citations was a review article published in the journal Emerging Infectious Diseases and titled Quinolone and macrolide resistance in Campylobacter jejuni and C. coli: Resistance mechanisms and trends in human isolates.

\section{Discussion}

In this study, a bibliometric overview of campylobacterrelated publications was sought and presented. Our study showed a gradual and fluctuating increase in the number of publications with time. Most publications originated from developed countries. Campylobacterrelated drug resistance publications also showed a noticeable increase in the past decade with quinolone and flouroquinolone resistance being most commonly emphasized. The result that the USA was the most productive was not surprising given that the USA ranked first in many other medical fields in quantity of publications $[73,74]$. However, the USA ranked fourth in number of citations per article. One potential explanation for this discrepancy is the extent of international collaboration in publications from the USA compared to that of from the UK or the Netherlands. This study is the first bibliometric study on a zoonotic foodborne disease. No doubt that diarrhea associated with bacterial infections such as campylobacteriosis, particularly in developing regions, requires better monitoring and screening for types of bacteria involved and their

Table 4 Top ten productive (active) institutions/organizations in publishing articles on Campylobacter (2000-2015)

\begin{tabular}{|c|c|c|c|c|}
\hline $\mathrm{SCR}^{\mathrm{a}}$ & Institution/organization & Frequency & $\% N=5552$ & Country \\
\hline $1 s t$ & Danmarks Tekniske Universitet & 150 & 2.7 & Denmark \\
\hline 2nd & USDA ARS Russell Research Center RRC & 138 & 2.5 & USA \\
\hline $3 r d$ & Wageningen University and Research Centre & 110 & 2.0 & Netherlands \\
\hline 4th & Belfast Health and Social Care Trust & 108 & 1.9 & UK \\
\hline 5 th & Helsingin Yliopisto & 98 & 1.8 & Finland \\
\hline 6th & Utrecht University & 93 & 1.7 & Netherlands \\
\hline 7th & lowa State University & 91 & 1.6 & USA \\
\hline 7th & Conseil national de recherches Canada & 91 & 1.6 & Canada \\
\hline 9th & Veterinary Laboratories Agency & 90 & 1.6 & UK \\
\hline 10th & USDA Agricultural Research Service, Washington DC & 87 & 1.6 & USA \\
\hline
\end{tabular}

Equal institutions were given the same ranking number and then a gap is left in the ranking numbers.

${ }^{a} S C R$ standard competition ranking 
Table 5 Top ten productive (active) authors in publishing articles on Campylobacter (2000-2015)

\begin{tabular}{lllcl}
\hline SCR $^{\text {a }}$ & Author & Frequency & $\% N=5552$ & Country \\
\hline 1st & Moore, J.E. & 111 & 2.0 & UK \\
2nd & Hänninen, M.L. & 80 & 1.4 & Finland \\
3rd & Wagenaar, J.A. & 76 & 1.4 & WHO \\
4th & Matsuda, M. & 73 & 1.3 & Japan \\
5th & Zhang, Q. & 63 & 1.1 & USA \\
6th & Millar, B.C. & 57 & 1.0 & UK \\
6th & Guerry, P. & 56 & 1.0 & USA \\
8th & Newell, D.G. & 56 & 1.0 & UK \\
8th & Wren, B.W. & 56 & 1.0 & UK \\
10th & Berrang, M.E. & 49 & 0.9 & USA \\
\hline
\end{tabular}

${ }^{a} S C R$ Standard competition ranking. Equal authors were given the same ranking number, and then a gap is left in the ranking numbers

susceptibility to traditional antibiotic therapy. More research efforts are required in this field.

The top ten cited articles on Campylobacter reveals that molecular biology and genomics of Campylobacter pathogen were the most important ones. Understanding the molecular biology and genomics will help understanding the pathogenesis of campylobacteriosis [75-78]. One of the top cited articles was about search for new bactericidal agents from plant active oils [59]. Search for inexpensive, available, and efficacious therapeutic agents for gastroenteritis is common in developing world where traditional herbal medicine is popular [79-81]. Other articles in the top ten list were on public health and the impact of campylobacteriosis on human health. Both food safety and antimicrobial resistance are core subjects of public health. Many reports have been published on foodborne infections and gastroenteritis in the form of outbreaks in Europe and many other countries. Similarly, combating antimicrobial resistance of campylobacter both at veterinary and human levels is a public health major concern [71, 82-85].

There are several studies regarding research activity in the field of infectious diseases in general and those pertaining to campylobacteriosis in specific. A review article on control measures of campylobactercontaminated poultry meat indicated that current intervention measures are ineffective and there is urgent need for more fundamental research on Campylobacter [86]. A commentary that appeared in Lancet indicated that research on neglected diseases such as diarrhea is needed and a faster action is required [87]. The slow and fluctuating increase in research activity on campylobacter could be attributed to lack of funding to such globally common bacterial diseases in favor of other diseases such as HIV, tuberculosis, lymphatic filariasis, schistosomiasis, salmonellosis, and malaria $[88,89]$. A study showed that $37 \%$ of infectious diseases affecting livestock animals are bacterial diseases and this should encourage funding agencies to support research on bacterial infectious diseases of livestock that could affect humans such as campylobacteriosis [90]. Unfortunately, the escalating funding for infectious diseases such as HIV created a shortage of funding for other diseases of global burden such as campylobacteriosis [91]. A study that compared research output and citations among three infectious diseases indicated that funding has a positive influence on research output and citations for a particular disease [92]. It could be concluded that in the case presented in this study for campylobacter research output that funding is an important factor, funding needs to be consistent and well planned based on global need, and collaboration in such funding is of extreme importance to help eradicate some of the neglected diseases of poverty such as diarrhea.

Table 6 Top ten productive (active) journals in publishing articles on Campylobacter (2000 - 2015)

\begin{tabular}{|c|c|c|c|c|}
\hline SCR & Journal & Frequency & $\% N=5552$ & IF \\
\hline $1 s t$ & Applied and Environmental Microbiology & 246 & 4.4 & 3.668 \\
\hline $1 s t$ & Journal of Food Protection & 246 & 4.4 & 1.849 \\
\hline $3 \mathrm{rd}$ & Journal of Clinical Microbiology & 185 & 3.3 & 3.993 \\
\hline 4 th & International Journal of Food Microbiology & 147 & 2.6 & 3.082 \\
\hline 5 th & Journal of Applied Microbiology & 132 & 2.4 & 2.479 \\
\hline 6 th & Epidemiology and Infection & 123 & 2.2 & 2.515 \\
\hline 7th & Plos One & 122 & 2.2 & 3.234 \\
\hline 8th & Poultry Science & 116 & 2.1 & 1.672 \\
\hline 9th & Infection and Immunity & 105 & 1.9 & 3.731 \\
\hline 10th & Foodborne Pathogens and Disease & 103 & 1.9 & 1.905 \\
\hline
\end{tabular}

SCR standard competition ranking, IF impact factor 
Table 7 Top ten cited articles on Campylobacter (2000-2015)

\begin{tabular}{|c|c|c|c|c|}
\hline Title & Year & Journal & $\begin{array}{l}\text { Number of } \\
\text { citations }\end{array}$ & $\begin{array}{l}\text { Type of } \\
\text { document }\end{array}$ \\
\hline $\begin{array}{l}\text { The genome sequence of the food-borne pathogen Campylobacter jejuni } \\
\text { reveals hypervariable sequences [61] }\end{array}$ & 2000 & Nature & 1223 & Article \\
\hline $\begin{array}{l}\text { Increased rectal mucosal enteroendocrine cells, T lymphocytes, and } \\
\text { increased gut permeability following acute Campylobacter enteritis and } \\
\text { in post-dysenteric irritable bowel syndrome [62] }\end{array}$ & 2000 & Gut & 776 & Article \\
\hline Campylobacter jejuni infections: update on emerging issues and trends [54] & 2001 & Clinical Infectious Diseases & 597 & Review \\
\hline $\begin{array}{l}\text { Bactericidal activities of plant essential oils and some of their isolated } \\
\text { constituents against Campylobacter jejuni, Escherichia coli, Listeria } \\
\text { monocytogenes, and Salmonella enterica [59] }\end{array}$ & 2002 & Journal of Food Protection & 567 & Article \\
\hline Multilocus sequence typing system for Campylobacter jejuni [55] & 2001 & Journal of Clinical Microbiology & 472 & Article \\
\hline $\begin{array}{l}\text { Quinolone and macrolide resistance in Campylobacter jejuni } \\
\text { and C. coli: resistance mechanisms and trends in human isolates [56] }\end{array}$ & 2001 & Emerging Infectious Diseases & 426 & Review \\
\hline $\begin{array}{l}N \text {-linked glycosylation in Campylobacter jejuni and its functional transfer } \\
\text { into E. coli [63] }\end{array}$ & 2002 & Science & 416 & Article \\
\hline Campylobacters as zoonotic pathogens: a food production perspective [4] & 2007 & International Journal of Food Microbiology & 341 & Review \\
\hline $\begin{array}{l}\text { Major structural differences and novel potential virulence mechanisms } \\
\text { from the genomes of multiple campylobacter species [57] }\end{array}$ & 2005 & PLoS Biology & 319 & Article \\
\hline $\begin{array}{l}\text { Risk factors for sporadic Campylobacter infection in the United States: } \\
\text { a case-control study in FoodNet sites [58] }\end{array}$ & 2004 & Clinical Infectious Diseases & 302 & Article \\
\hline
\end{tabular}

Our study showed that campylobacter-related drug resistance publications were reported from different parts of the world suggesting that such a problem is a global problem [93-98]. Antimicrobial resistance among Campylobacter has developed mainly as a result of irrational use of antimicrobial agents in veterinary practices and food industry [99, 100]. Resistance to macrolides, flouroquinolones, and betalactams has been reported [56, 101-104]. The mechanisms involved in resistance to flouroquinolone

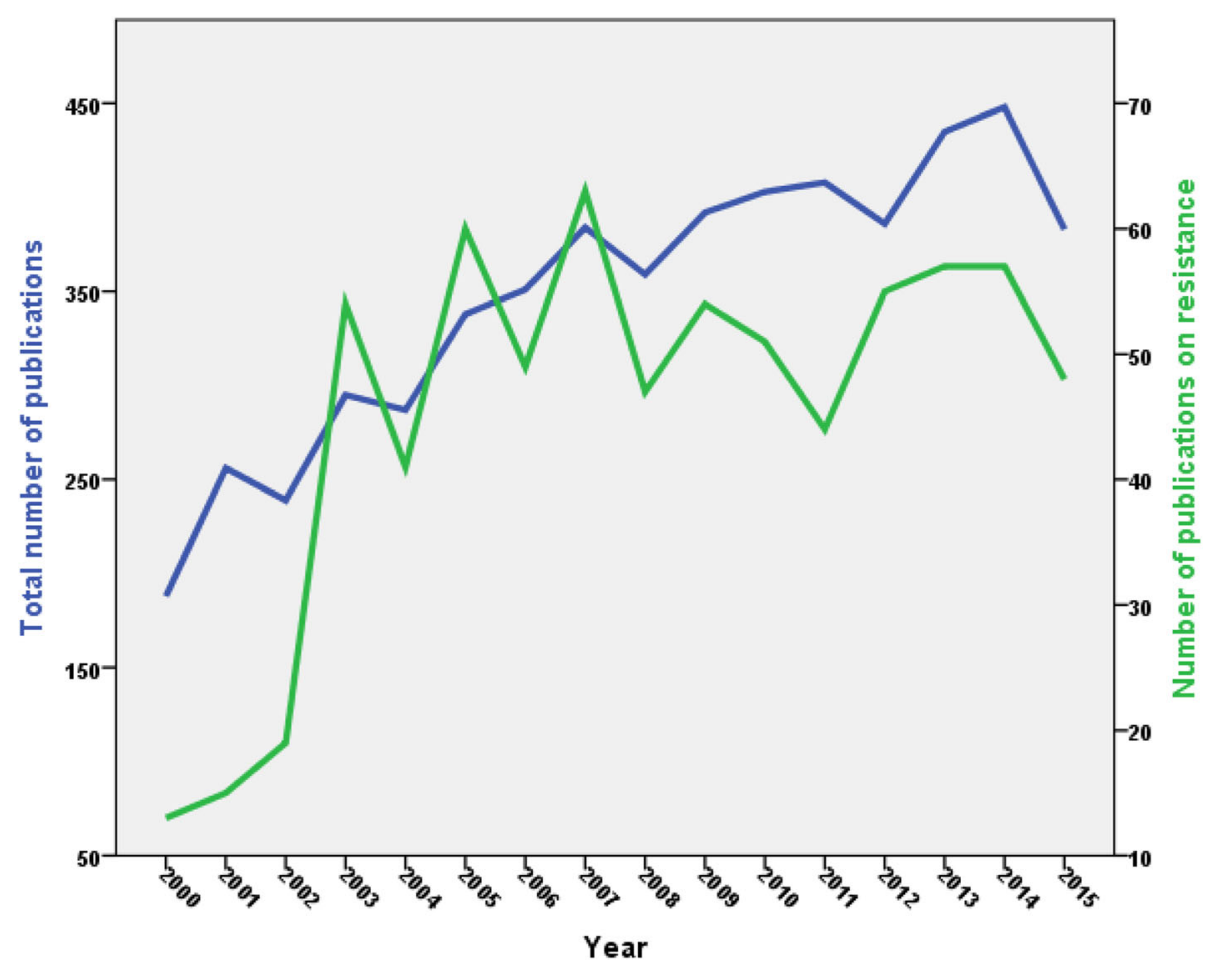

Fig. 2 Annual growth of publications on Campylobacter and campylobacter-related drug resistance (2000-2015) 
Table 8 Top ten productive (active) countries in publishing articles on campylobacter-related drug resistance (2000-2015)

\begin{tabular}{lllc}
\hline SCR $^{\text {a }}$ & Country & Frequency & $\%$ N $=5552$ \\
\hline 1st & USA & 168 & 23.1 \\
2nd & UK & 59 & 8.1 \\
3rd & Canada & 54 & 7.4 \\
4th & France & 38 & 5.2 \\
5th & Japan & 35 & 4.8 \\
6th & Finland & 28 & 3.8 \\
7th & China & 27 & 3.7 \\
8th & Thailand & 25 & 3.4 \\
9th & Denmark & 24 & 3.3 \\
9th & Ireland & 24 & 3.3 \\
9th & Poland & 24 & 3.3
\end{tabular}

Equal countries were given the same ranking number, and then a gap is left in the ranking numbers.

${ }^{\mathrm{a}} S C R$ standard competition ranking

include mutations in the target enzyme called gyrase which is involved in bacterial DNA replication and repair [66, 103, 105]. Another important mechanism of resistance to quinolones includes efflux mechanism [68].

Our study has few limitations that need to be considered when interpreting the results. Like all bibliometric studies [38, 39, 42, 106-109], false positive and false negative results are unavoidable because there is no perfect and comprehensive research query. Therefore, we might have missed some articles either due to search query or to the use of title search rather than title/abstract search. Despite the fact that Scopus is one of the largest databases, there are some journals that are not indexed in Scopus, and therefore, articles on Campylobacter published in these unindexed journals were definitely missed. Furthermore, the citation analysis did not exclude selfcitation, and therefore, ranking based on citations or citation per article might be misleading in certain cases.

\section{Conclusions}

The number of publications on Campylobacter and on campylobacter-related drug resistance showed a clear rise in the past decade. Northern America and European countries are leading research on Campylobacter. Publications focused mainly on molecular biology/genetics and public health burden of campylobacteriosis. Research on rational drug use of antimicrobials in human, poultry, and animals is highly recommended to limit the emergence of antimicrobial resistance in Campylobacter. Furthermore, international collaboration is highly required particularly in implementing new diagnostic screening technologies for Campylobacter detection to ensure food safety.

Table 9 Top cited articles on campylobacter-related drug resistance (2000-2015)

\begin{tabular}{|c|c|c|c|c|}
\hline Title & Year & Source title & $\begin{array}{l}\text { Number of } \\
\text { citations }\end{array}$ & $\begin{array}{l}\text { Document } \\
\text { type }\end{array}$ \\
\hline $\begin{array}{l}\text { Quinolone and macrolide resistance in Campylobacter jejuni and } \\
\text { C. coli: resistance mechanisms and trends in human isolates [56] }\end{array}$ & 2001 & Emerging Infectious Diseases & 426 & Review \\
\hline $\begin{array}{l}\text { Antibiotic resistance in Campylobacter strains isolated from animals, } \\
\text { foods, and humans in Spain in 1997-1998 [72] }\end{array}$ & 2000 & $\begin{array}{l}\text { Antimicrobial Agents and } \\
\text { Chemotherapy }\end{array}$ & 218 & Article \\
\hline $\begin{array}{l}\text { Fluoroquinolone-resistant Campylobacter species and the withdrawal of } \\
\text { fluoroquinolones from use in poultry: a public health success story [71] }\end{array}$ & 2007 & Clinical Infectious Diseases & 171 & Review \\
\hline $\begin{array}{l}\text { Antimicrobial resistance among Campylobacter strains, United States, } \\
\text { 1997-2001 [69] }\end{array}$ & 2004 & Emerging Infectious Diseases & 166 & Article \\
\hline $\begin{array}{l}\text { Enhanced in vivo fitness of fluoroquinolone-resistant Campylobacter } \\
\text { jejuni in the absence of antibiotic selection pressure [70] }\end{array}$ & 2005 & $\begin{array}{l}\text { Proceedings of the National Academy } \\
\text { of Sciences }\end{array}$ & 162 & Article \\
\hline $\begin{array}{l}\text { Prevalence and antimicrobial susceptibility of thermophilic campylobacter } \\
\text { in organic and conventional broiler flocks [65] }\end{array}$ & 2001 & Letters in Applied Microbiology & 157 & Article \\
\hline $\begin{array}{l}\text { Occurrence and resistance to antibiotics of Campylobacter jejuni and } \\
\text { Campylobacter coli in animals and meat in northeastern Italy [67] }\end{array}$ & 2003 & $\begin{array}{l}\text { International Journal of Food } \\
\text { Microbiology }\end{array}$ & 145 & Article \\
\hline $\begin{array}{l}\text { In vivo selection of Campylobacter isolates with high levels of } \\
\text { fluoroquinolone resistance associated with gyrA mutations and the } \\
\text { function of the CmeABC efflux pump [66] }\end{array}$ & 2003 & $\begin{array}{l}\text { Antimicrobial Agents and } \\
\text { Chemotherapy }\end{array}$ & 138 & Article \\
\hline $\begin{array}{l}\text { Critical role of multidrug efflux pump } C \text { meABC in bile resistance and } \\
\text { in vivo colonization of Campylobacter jejuni [68] }\end{array}$ & 2003 & Infection and Immunity & 132 & Article \\
\hline $\begin{array}{l}\text { Antimicrobial susceptibilities of Campylobacter strains isolated from food } \\
\text { animals in Belgium [64] }\end{array}$ & 2001 & Journal of Antimicrobial Chemotherapy & 132 & Article \\
\hline
\end{tabular}




\section{Abbreviations}

CDC: Centers for Disease Control and Prevention; IF: Impact factor; SCP: Single country publications; SCR: Standard competition ranking; WHO: World Health Organization

\section{Acknowledgements}

None.

\section{Funding}

None.

\section{Availability of data and materials}

All data present in this article can be retrieved from Scopus using keywords listed in the methodology.

\section{Authors' contributions}

WS and SZ carried out the idea, concept, and manuscript preparation. SJ, AA and AS participated in the data extraction, analysis, and presentation. All authors read and approved the final manuscript.

\section{Competing interests}

The authors declare that they have no competing interests.

\section{Consent for publication}

Not applicable.

\section{Ethics approval and consent to participate}

Not applicable.

\section{Author details}

${ }^{1}$ Department of Physiology, Pharmacology and Toxicology, College of Medicine and Health Sciences, An-Najah National University, Nablus, Palestine ${ }^{2}$ Department of Clinical and Community Pharmacy, College of Medicine and Health Sciences, An-Najah National University, Nablus, Palestine.

\section{Received: 19 June 2016 Accepted: 22 November 2016}

\section{Published online: 29 November 2016}

\section{References}

1. Man SM. The clinical importance of emerging Campylobacter species. Nat Rev Gastroenterol Hepatol. 2011;8(12):669-85.

2. Lee S, Lee J, Ha J, Choi Y, Kim S, Lee H, et al. Clinical relevance of infections with zoonotic and human oral species of Campylobacter. J Microbiol. 2016; 54(7):459-67.

3. Wilson DJ, Gabriel E, Leatherbarrow AJ, Cheesbrough J, Gee S, Bolton E, et al. Tracing the source of campylobacteriosis. PLoS Genet. 2008;4(9): e1000203.

4. Silva J, Leite D, Fernandes M, Mena C, Gibbs PA, Teixeira P. Campylobacter spp. as a Foodborne Pathogen: A Review. Front Microbiol. 2011;2:200.

5. Sarkar SR, Hossain MA, Paul SK, Ray NC, Sultana S, Rahman MM, et al. Campylobacteriosis_an overview. Mymensingh Med J. 2014;23(1):173-80

6. Golz G, Rosner B, Hofreuter D, Josenhans C, Kreienbrock L, Lowenstein A, et al. Relevance of Campylobacter to public health-the need for a One Health approach. Int J Med Microbiol. 2014:304(7):817-23.

7. Kaakoush NO, Castano-Rodriguez N, Mitchell HM, Man SM. Global epidemiology of Campylobacter infection. Clin Microbiol Rev. 2015;28(3): 687-720.

8. Taniuchi M, Sobuz SU, Begum S, Platts-Mills JA, Liu J, Yang Z, et al. Etiology of diarrhea in Bangladeshi infants in the first year of life analyzed using molecular methods. J Infect Dis. 2013:208(11):1794-802.

9. Rao MR, Naficy AB, Savarino SJ, Abu-Elyazeed R, Wierzba TF, Peruski LF, et al. Pathogenicity and convalescent excretion of Campylobacter in rural Egyptian children. Am J Epidemiol. 2001;154(2):166-73.

10. Pazzaglia G, Bourgeois AL, el Diwany K, Nour N, Badran N, Hablas R. Campylobacter diarrhoea and an association of recent disease with asymptomatic shedding in Egyptian children. Epidemiol Infect. 1991; 106(1):77-82.

11. Nichols GL, Richardson JF, Sheppard SK, Lane C, Sarran C. Campylobacter epidemiology: a descriptive study reviewing 1 million cases in England and Wales between 1989 and 2011. BMJ Open. 2012;2(4):e001179.
12. Kubota K, Kasuga F, Iwasaki E, Inagaki S, Sakurai Y, Komatsu M, et al. Estimating the burden of acute gastroenteritis and foodborne illness caused by Campylobacter, Salmonella, and Vibrio parahaemolyticus by using population-based telephone survey data, Miyagi Prefecture, Japan, 2005 to 2006. J Food Prot. 2011;74(10):1592-8.

13. Scallan E, Hoekstra RM, Angulo FJ, Tauxe RV, Widdowson MA, Roy SL, et al. Foodborne illness acquired in the United States-major pathogens. Emerg Infect Dis. 2011;17(1):7-15.

14. Fitzgerald C. Campylobacter. Clin Lab Med. 2015;35(2):289-98.

15. Centers for Diseases Prevention and Control. Foodborne Diseases Active Surveillance Network (FoodNet). 2014. https://www.cdc.gov/foodnet/ reports/annual-reports-2014.html. Accessed October 302016

16. Food Standard Agency. FSA warns that chicken bacteria could be next meat scandal. In: The Telegraph. 2013. http://www.telegraph.co.uk/ foodanddrink/foodanddrinknews/9820838/FSA-warns-that-chicken-bacteriacould-be-next-meat-scandal.html. Accessed November 22016.

17. de Wit MA, Koopmans MP, Kortbeek LM, Wannet WJ, Vinje J, van Leusden F, et al. Sensor, a population-based cohort study on gastroenteritis in the Netherlands: incidence and etiology. Am J Epidemiol. 2001;154(7):666-74.

18. Havelaar AH, Haagsma JA, Mangen MJ, Kemmeren JM, Verhoef LP, Vijgen SM, et al. Disease burden of foodborne pathogens in the Netherlands, 2009. Int J Food Microbiol. 2012;156(3):231-8.

19. Tam CC, Rodrigues LC, Viviani L, Dodds JP, Evans MR, Hunter PR, et al. Longitudinal study of infectious intestinal disease in the UK (IID2 study): incidence in the community and presenting to general practice. Gut. 2012;61(1):69-77.

20. World Health Organization. Campylobacter. 2011. http://www.who.int/ mediacentre/factsheets/fs255/en/. Accessed June 162016.

21. McCrackin MA, Helke KL, Galloway AM, Poole AZ, Salgado CD, Marriott BP. Effect of antimicrobial use in agricultural animals on drug-resistant foodborne campylobacteriosis in humans: a systematic literature review. Crit Rev Food Sci Nutr. 2016;56(13):2115-32

22. Shin $E_{1}$ Hong $H$, Oh $Y$, Lee $Y$. First report and molecular characterization of campylobacter jejuni isolate with extensive drug resistance from a travelassociated human case. Antimicrob Agents Chemother. 2015:59(10):6670-2.

23. Kashoma IP, Kassem II, John J, Kessy BM, Gebreyes W, Kazwala RR, et al. Prevalence and antimicrobial resistance of campylobacter isolated from dressed beef carcasses and Raw milk in Tanzania. Microb Drug Resist. 2016; 22(1):40-52.

24. Chen J, Yu Y, Wang J, Gu Y, Sun X, Xu J, et al. Three cases of acute gastroenteritis caused by high-level macrolideresistant Campylobacter: drug resistance mechanisms and clinical characteristics. Scand J Infect Dis. 2012 44(7):541-3.

25. Agunos A, Leger D, Avery BP, Parmley EJ, Deckert A, Carson CA, et al. Ciprofloxacin-resistant Campylobacter spp. in retail chicken, western Canada. Emerg Infect Dis. 2013:19(7):1121-4

26. Mukherjee $P$, Ramamurthy T, Mitra U, Mukhopadhyay AK. Emergence of high-level azithromycin resistance in Campylobacter jejuni isolates from pediatric diarrhea patients in Kolkata. India Antimicrob Agents Chemother. 2014:58(7):4248.

27. Centers for Disease Control and Prevention. Antibiotic? Antimicrobial resistance 2016. https://www.cdc.gov/drugresistance/. Accessed November 12016.

28. Trapero-Marugán M, Gisbert JP, Pajares JM. Spanish scientific output on Helicobacter pylori. A study through Medline. Rev Esp Enferm Dig. 2006; 98(4):255-64.

29. Suk FM, Lien GS, Yu TC, Ho YS. Global trends in Helicobacter pylori research from 1991 to 2008 analyzed with the Science Citation Index Expanded. Eur J Gastroenterol Hepatol. 2011;23(4):295-301.

30. Chou L-F. Medline-based bibliometric analysis of gastroenterology journals between 2001 and 2007. World J Gastroenterol. 2009;15(23):2933-9.

31. Khatun A, Ahmed S. A bibliometric analysis of diarrhoeal disease research in Bangladesh. ALIS. 2011;58(2):109-17.

32. Loomes DE, van Zanten SV. Bibliometrics of the top 100 clinical articles in digestive disease. Gastroenterology. 2013;144(4):673-6. e5.

33. Chen T-J, Chen Y-C, Hwang S-J, Chou L-F. The rise of China in gastroenterology? A bibliometric analysis of ISI and Medline databases. Scientometrics. 2006:69(3):539-49.

34. World Health Organization. The global view of campylobacteriosis: report of an expert consultation. 2013. http://apps.who.int/iris/bitstream/10665/ 80751/1/9789241564601_eng.pdf. Accessed November 22016.

35. Fenwick A. The global burden of neglected tropical diseases. Public Health. 2012;126(3):233-6. 
36. Falagas ME, Pitsouni El, Malietzis GA, Pappas G. Comparison of PubMed, Scopus, Web of Science, and Google Scholar: strengths and weaknesses. Faseb j. 2008;22(2):338-42.

37. Sweileh WM. Bibliometric analysis of literature on female genital mutilation: (1930 - 2015). Reprod Health. 2016;13(1):130

38. Sweileh WM, Al-Jabi SW, Sawalha AF, Zyoud SH. Bibliometric profile of the global scientific research on autism spectrum disorders. Springerplus. 2016; 5(1):1480.

39. Sweileh WM, Shraim NY, Al-Jabi SW, Sawalha AF, AbuTaha AS, Zyoud SH Bibliometric analysis of global scientific research on carbapenem resistance (1986-2015). Ann Clin Microbiol Antimicrob. 2016;15(1):56.

40. Sweileh WM, Shraim NY, Al-Jabi SW, Sawalha AF, Rahhal B, Khayyat RA, et al. Assessing worldwide research activity on probiotics in pediatrics using Scopus database: 1994-2014. World Allergy Organ J. 2016;9:25

41. Sweileh WM, Shraim NY, Zyoud SH, Al-Jabi SW. Worldwide research productivity on tramadol: a bibliometric analysis. Springerplus. 2016;5(1):1108

42. Sweileh WM, Zyoud SH, Al-Jabi SW, Sawalha AF, Shraim NY. Drinking and recreational water-related diseases: a bibliometric analysis (1980-2015). Ann Occup Environ Med. 2016;28(1):40.

43. Andersen-Nissen E, Smith KD, Strobe KL, Barrett SL, Cookson BT, Logan SM et al. Evasion of Toll-like receptor 5 by flagellated bacteria. Proc Natl Acad Sci U S A. 2005;102(26):9247-52.

44. Brouqui P, Raoult D. Endocarditis due to rare and fastidious bacteria. Clin Microbiol Rev. 2001;14(1):177-207.

45. Butler J, MacCallum I, Kleber M, Shlyakhter IA, Belmonte MK, Lander ES, et al. ALLPATHS: de novo assembly of whole-genome shotgun microreads. Genome Res. 2008;18(5):810-20.

46. Dowd SE, Callaway TR, Wolcott RD, Sun Y, McKeehan T, Hagevoort RG, et al. Evaluation of the bacterial diversity in the feces of cattle using 165 rDNA bacterial tag-encoded FLX amplicon pyrosequencing (bTEFAP). BMC Microbiol. 2008;8:125

47. Dunlop SP, Jenkins D, Neal KR, Spiller RC. Relative importance of enterochromaffin cell hyperplasia, anxiety, and depression in postinfectious IBS. Gastroenterology. 2003;125(6):1651-9.

48. Feil EJ, Li BC, Aanensen DM, Hanage WP, Spratt BG. eBURST: inferring patterns of evolutionary descent among clusters of related bacterial genotypes from multilocus sequence typing data. J Bacteriol. 2004;186(5):1518-30.

49. McEwen SA, Fedorka-Cray PJ. Antimicrobial use and resistance in animals. Clin Infect Dis. 2002;34 Suppl 3:S93-S106.

50. van Doorn PA, Ruts $L$, Jacobs BC. Clinical features, pathogenesis, and treatment of Guillain-Barre syndrome. Lancet Neurol. 2008;7(10):939-50.

51. Willison HJ, Yuki N. Peripheral neuropathies and anti-glycolipid antibodies. Brain. 2002;125(Pt 12):2591-625

52. Hirsch JE. An index to quantify an individual's scientific research output Proc Natl Acad Sci U S A. 2005;102(46):16569-72.

53. Thomson Reuters. Journal Citation Reports. 2015. https://jcr.incites. thomsonreuters.com/. Accessed August 72016.

54. Allos BM. Campylobacter jejuni infections: update on emerging issues and trends. Clin Infect Dis. 2001:32(8):1201-6.

55. Dingle KE, Colles FM, Wareing DR, Ure R, Fox AJ, Bolton FE, et al. Multilocus sequence typing system for Campylobacter jejuni. J Clin Microbiol. 2001; 39(1):14-23.

56. Engberg J, Aarestrup FM, Taylor DE, Gerner-Smidt P, Nachamkin I. Quinolone and macrolide resistance in Campylobacter jejuni and C. coli: resistance mechanisms and trends in human isolates. Emerg Infect Dis, 2001;7(1):24-34.

57. Fouts DE, Mongodin EF, Mandrell RE, Miller WG, Rasko DA, Ravel J, et al. Major structural differences and novel potential virulence mechanisms from the genomes of multiple campylobacter species. PLoS Biol. 2005;3(1):e15.

58. Friedman CR, Hoekstra RM, Samuel M, Marcus R, Bender J, Shiferaw B, et al. Risk factors for sporadic Campylobacter infection in the United States: a case-control study in FoodNet sites. Clin Infect Dis. 2004;38 Suppl 3:S285-96.

59. Friedman M, Henika PR, Mandrell RE. Bactericidal activities of plant essential oils and some of their isolated constituents against Campylobacter jejuni, Escherichia coli, Listeria monocytogenes, and Salmonella enterica. J Food Prot. 2002;65(10):1545-60.

60. Humphrey T, O'Brien S, Madsen M. Campylobacters as zoonotic pathogens: a food production perspective. Int J Food Microbiol. 2007;117(3):237-57.

61. Parkhill J, Wren BW, Mungall K, Ketley JM, Churcher C, Basham D, et al. The genome sequence of the food-borne pathogen Campylobacter jejuni reveals hypervariable sequences. Nature. 2000;403(6770):665-8.
62. Spiller RC, Jenkins D, Thornley JP, Hebden JM, Wright T, Skinner M, et al. Increased rectal mucosal enteroendocrine cells, T lymphocytes, and increased gut permeability following acute Campylobacter enteritis and in post-dysenteric irritable bowel syndrome. Gut. 2000:47(6):804-11.

63. Wacker M, Linton D, Hitchen PG, Nita-Lazar M, Haslam SM, North SJ, et al. $\mathrm{N}$-linked glycosylation in Campylobacter jejuni and its functional transfer into E. coli. Science. 2002;298(5599):1790-3.

64. Van Looveren M, Daube G, De Zutter L, Dumont JM, Lammens C, Wijdooghe $M$, et al. Antimicrobial susceptibilities of Campylobacter strains isolated from food animals in Belgium. J Antimicrob Chemother. 2001;48(2): 235-40.

65. Heuer OE, Pedersen K, Andersen JS, Madsen M. Prevalence and antimicrobial susceptibility of thermophilic Campylobacter in organic and conventional broiler flocks. Lett Appl Microbiol. 2001;33(4):269-74.

66. Luo N, Sahin O, Lin J, Michel LO, Zhang Q. In vivo selection of Campylobacter isolates with high levels of fluoroquinolone resistance associated with gyrA mutations and the function of the CmeABC efflux pump. Antimicrob Agents Chemother. 2003;47(1):390-4.

67. Pezzotti G, Serafin A, Luzzi I, Mioni R, Milan M, Perin R. Occurrence and resistance to antibiotics of Campylobacter jejuni and Campylobacter coli in animals and meat in northeastern Italy. Int J Food Microbiol. 2003;82(3):281-7.

68. Lin J, Sahin O, Michel LO, Zhang Q. Critical role of multidrug efflux pump CmeABC in bile resistance and in vivo colonization of Campylobacter jejuni. Infect Immun. 2003;71(8):4250-9.

69. Gupta A, Nelson JM, Barrett TJ, Tauxe RV, Rossiter SP, Friedman CR, et al. Antimicrobial resistance among Campylobacter strains, United States, $1997-$ 2001. Emerg Infect Dis. 2004;10(6):1102-9.

70. Luo N, Pereira S, Sahin O, Lin J, Huang S, Michel L, et al. Enhanced in vivo fitness of fluoroquinolone-resistant Campylobacter jejuni in the absence of antibiotic selection pressure. Proc Natl Acad Sci U S A. 2005;102(3):541-6.

71. Nelson JM, Chiller TM, Powers JH, Angulo FJ. Fluoroquinolone-resistant Campylobacter species and the withdrawal of fluoroquinolones from use in poultry: a public health success story. Clin Infect Dis. 2007;44(7):977-80.

72. Sáenz Y, Zarazaga M, Lantero M, Gastañares MJ, Baquero F, Torres C. Antibiotic resistance in Campylobacter strains isolated from animals, foods, and humans in Spain in 1997-1998. Antimicrob Agents Chemother. 2000; 44(2):267-71.

73. Cruz-Calderon S, Nasner-Posso KM, Alfaro-Toloza P, Paniz-Mondolfi AE, Rodriguez-Morales AJ. A bibliometric analysis of global Ebola research. Travel Med Infect Dis. 2015;13(2):202-4.

74. Fricke R, Uibel S, Klingelhoefer D, Groneberg DA. Influenza: a scientometric and density-equalizing analysis. BMC Infect Dis. 2013;13(1):454.

75. Young KT, Davis LM, Dirita VJ. Campylobacter jejuni: molecular biology and pathogenesis. Nat Rev Microbiol. 2007;5(9):665-79.

76. Hendrixson DR, DiRita VJ. Identification of Campylobacter jejuni genes involved in commensal colonization of the chick gastrointestinal tract. Mol Microbiol. 2004:52(2):471-84.

77. Konkel ME, Kim BJ, Rivera-Amill V, Garvis SG. Bacterial secreted proteins are required for the internalization of Campylobacter jejuni into cultured mammalian cells. Mol Microbiol. 1999;32(4):691-701.

78. Novik V, Hofreuter D, Galan JE. Identification of Campylobacter jejuni genes involved in its interaction with epithelial cells. Infect Immun. 2010;78(8): 3540-53.

79. Ravishankar S, Zhu L, Law B, Joens L, Friedman M. Plant-derived compounds inactivate antibiotic-resistant Campylobacter jejuni strains. J Food Prot. 2008; 71(6):1145-9.

80. Gutiérrez SP, Sánchez MAZ, González CP, García LA. Antidiarrhoeal activity of different plants used in traditional medicine. Afr J Biotechnol. 2007;6(25): 2988-94.

81. Samie A, Obi CL, Lall N, Meyer JJ. In-vitro cytotoxicity and antimicrobial activities, against clinical isolates of Campylobacter species and Entamoeba histolytica, of local medicinal plants from the Venda region, in South Africa. Ann Trop Med Parasitol. 2009;103(2):159-70.

82. Frost JA, Gillespie IA, O'Brien SJ. Public health implications of campylobacter outbreaks in England and Wales, 1995-9: epidemiological and microbiological investigations. Epidemiol Infect. 2002;128(2):111-8.

83. Tauxe RV. Emerging foodborne diseases: an evolving public health challenge. Emerg Infect Dis. 1997;3(4):425-34.

84. Harris NV, Weiss NS, Nolan CM. The role of poultry and meats in the etiology of Campylobacter jejuni/coli enteritis. Am J Public Health. 1986; 76(4):407-11. 
85. Altekruse SF, Stern NJ, Fields PI, Swerdlow DL. Campylobacter jejuni-an emerging foodborne pathogen. Emerg Infect Dis. 1999;5(1):28-35.

86. Hermans D, Van Deun K, Messens W, Martel A, Van Immerseel F, Haesebrouck F, et al. Campylobacter control in poultry by current intervention measures ineffective: urgent need for intensified fundamental research. Vet Microbiol. 2011;152(3-4):219-28.

87. Utzinger J, Keiser J. Research and development for neglected diseases: more is still needed, and faster. Lancet Glob Health. 2013;1(6):e317-8.

88. Allen T, Parker M. Will increased funding for neglected tropical diseases really make poverty history? Lancet. 2012;379(9821):1097-8.

89. Eurosurveillance editorial team. The European Union provides funding to strengthen the protection against zoonoses and animal diseases. Euro Surveill. 2011;16(46).

90. Ducrot C, Gautret M, Pineau T, Jestin A. Scientific literature on infectious diseases affecting livestock animals, longitudinal worldwide bibliometric analysis. Vet Res. 2016;47(1):42.

91. Fleischer T, Kevany S, Benatar SR. Will escalating spending on HIV treatment displace funding for treatment of other diseases? S Afr Med J. 2010;100(1): 32-4.

92. Head MG, Fitchett JR, Derrick G, Wurie FB, Meldrum J, Kumari N, et al. Comparing research investment to United Kingdom institutions and published outputs for tuberculosis, HIV and malaria: a systematic analysis across 1997-2013. Health Res Policy Syst. 2015;13(1):63.

93. Chen X, Naren GW, Wu CM, Wang Y, Dai L, Xia LN, et al. Prevalence and antimicrobial resistance of Campylobacter isolates in broilers from China. Vet Microbiol. 2010;144(1-2):133-9.

94. Dallal MMS, Doyle MP, Rezadehbashi M, Dabiri H, Sanaei M, Modarresi S, et al. Prevalence and antimicrobial resistance profiles of Salmonella serotypes, Campylobacter and Yersinia spp. isolated from retail chicken and beef, Tehran, Iran. Food Control. 2010;21(4):388-92.

95. Ghosh R, Uppal B, Aggarwal P, Chakravarti A, Jha AK. Increasing antimicrobial resistance of Campylobacter jejuni isolated from paediatric diarrhea cases in a tertiary care hospital of New Delhi, India. J Clin Diagn Res. 2013;7(2):247-9.

96. Gallay A, Prouzet-Mauleon V, Kempf I, Lehours P, Labadi L, Camou C, et al. Campylobacter antimicrobial drug resistance among humans, broiler chickens, and pigs. France Emerg Infect Dis. 2007;13(2):259-66.

97. Miflin JK, Templeton JM, Blackall PJ. Antibiotic resistance in Campylobacter jejuni and Campylobacter coli isolated from poultry in the South-East Queensland region. J Antimicrob Chemother. 2007;59(4):775-8.

98. Gaudreau C, Boucher F, Gilbert H, Bekal S. Antimicrobial susceptibility of Campylobacter jejuni and Campylobacter coli isolates obtained in Montreal, Quebec, Canada, from 2002 to 2013. J Clin Microbiol. 2014;52(7):2644-6.

99. Aarestrup FM, Wegener HC. The effects of antibiotic usage in food animals on the development of antimicrobial resistance of importance for humans in Campylobacter and Escherichia coli. Microbes Infect. 1999;1(8):639-44.

100. Hidano A, Yamamoto T, Hayama Y, Muroga N, Kobayashi S, Nishida T, et al. Antimicrobial resistance among Campylobacter isolates obtained from retail chicken meat and offal products in Japan. Jpn J Infect Dis. 2014;67(4):315-7.

101. Fliegelman RM, Petrak RM, Goodman LJ, Segreti J, Trenholme GM, Kaplan RL. Comparative in vitro activities of twelve antimicrobial agents against Campylobacter species. Antimicrob Agents Chemother. 1985;27(3):429-30.

102. Hardy DJ, Hanson CW, Hensey DM, Beyer JM, Fernandes PB. Susceptibility of Campylobacter pylori to macrolides and fluoroquinolones. J Antimicrob Chemother. 1988;22(5):631-6.

103. Payot S, Bolla JM, Corcoran D, Fanning S, Megraud F, Zhang Q. Mechanisms of fluoroquinolone and macrolide resistance in Campylobacter spp. Microbes Infect. 2006;8(7):1967-71.

104. Alfredson DA, Korolik V. Antibiotic resistance and resistance mechanisms in Campylobacter jejuni and Campylobacter coli. FEMS Microbiol Lett. 2007; 277(2):123-32.

105. Ruiz J. Mechanisms of resistance to quinolones: target alterations, decreased accumulation and DNA gyrase protection. J Antimicrob Chemother. 2003; 51(5):1109-17

106. Zyoud SH. Dengue research: a bibliometric analysis of worldwide and Arab publications during 1872-2015. Virol J. 2016;13:78.

107. Zyoud SH. Global research trends of Middle East respiratory syndrome coronavirus: a bibliometric analysis. BMC Infect Dis. 2016;16:255.

108. Zyoud SH, Al-Jabi SW, Sweileh WM, Awang R. Contribution of Arab countries to pharmaceutical wastewater literature: a bibliometric and comparative analysis of research output. Ann Occup Environ Med. 2016;28:28.

109. Zyoud SH, Waring WS, Al-Jabi SW, Sweileh WM, Rahhal B, Awang R. Intravenous lipid emulsion as an antidote for the treatment of acute poisoning: a bibliometric analysis of human and animal studies. Basic Clin Pharmacol Toxicol. 2016;119(5):512-9.

\section{Submit your next manuscript to BioMed Central and we will help you at every step:}

- We accept pre-submission inquiries

- Our selector tool helps you to find the most relevant journal

- We provide round the clock customer support

- Convenient online submission

- Thorough peer review

- Inclusion in PubMed and all major indexing services

- Maximum visibility for your research

Submit your manuscript at www.biomedcentral.com/submit
) Biomed Central 